\title{
LogForum
}

$>$ Scientific Journal of Logistics <

2020, $16(3), 333-345$

http://doi.org/10.17270/J.LOG.2020.409

http://www.logforum.net p-ISSN 1895-2038

e-ISSN 1734-459X

ORIGINAL PAPER

\section{THE ALGORITHM OF DEVELOPING PRIORITIES IN THE SUPPLY CHAIN}

\author{
Bożena Zwolińska ${ }^{1}$, Agnieszka A. Tubis ${ }^{2}$ \\ 1) AGH University of Science and Technology, Krakow, Poland, 2) Wroclaw University of Science and Technology, \\ Wroclaw, Poland
}

\begin{abstract}
Background: The presented research problem concerns the operational (executive) level and does not include tactical or strategic solutions. The described algorithm concerns the determination of the priority number of objects that are the equipment of any considered production system. The algorithm takes into account the states of work in the external and internal areas of the evaluated system. The analysed characteristics mainly include: values of work levels in the supply chain (to and from the enterprise) and values of system work levels within the company in the area of continuity of the processed material flow and failure levels of technological equipment. The algorithm of the object priority evaluation takes into account the existing synergy of a single element of the system with the whole system.

Methods: The presented method of assessing priorities enables determination of critical elements of a complex system. The evaluation is carried out in a three-dimensional system. It takes into account machine failure, the operation of processes in the area of the analysed manufacturing system but also the levels of operation of supply systems (supply chains). The presented method of determining priorities requires adapting the assessment methodology to the individual characteristics of the test object. For this reason, the analysis includes, among others: the type of the system, its structural and functional complexity, complexity of interoperability and the size of material flow streams and their frequency.

Results: The developed algorithm was verified on a selected example of a production system. Due to the complexity of the presented algorithm, the article presents results for a system that is characterized by a relatively high level of process flexibility and has a large number of technological processes. The article presents the values of indicators that were calculated for individual modules

Conclusions: The presented algorithm is a general approach to the evaluation of the elementary objects of the system, while taking into account the existing synergy between the other elements of the entire system. In the next stages of the research, the authors will develop algorithms for various production systems (convergent and divergent), for different manufacturing specifications (objective and technological) and for different levels of process flexibility values.
\end{abstract}

Key words: priorities of objects, supply chain.

A part of this study was presented as oral presentation at the „8th International Logistics Scientific Conference WSL FORUM 2019” in Poznan (Poland), 18th-19th of November 2019.

\section{INTRODUCTION}

The effectiveness of any complex system depends on many factors. The most frequently indicated here are: efficiency and reliability of components, the level of quality of tasks implementation defined for the whole system and its individual links, the degree of connections between components, the level of complexity of relationships occurring within the system and between the system and the environment. The levels of system operation parameters occur in their close correlation and create the global effectiveness of the entire system or each isolated link. Each improvement in the level of the assessed indicator being perceived as the system 
improvement, determines the changes in the operating parameters of interdependent links/components (not necessarily positive). Therefore, thoughtful and fully effective implementation of improvement solutions should take into account a holistic approach in the existing relationships.

The use of multi-faceted criteria for assessing complex technical systems is a NPhard task. Formulating algorithms that define levels of effective work, which take into account the synergy of the system with its individual elements is a time-consuming process and requires knowledge of existing intra-system relationships. The degree of difficulty and time consumption of the algorithms prepared for complex systems increases exponentially with the number of components considered. For this reason, the first analyses and tests are formulated for simplified systems. However, the obtained results are determined for isolated systems.

The article presents the algorithm for determining the priority value level for the components of any logistics system. The developed algorithm comprehensively considers the system at the operational level, including the time and spatial horizon. The priority values determined according to the model for the analysed objects are multicriteria. They take into account the location of the evaluated element in relation to the bottleneck (theory of constraints) and in relation to the client.

The main goal of the article is to formulate an algorithm for creating priority values - PV for any object of a complex logistics system. The developed algorithm PV takes into account existing intra-system correlations and individual operating parameters of the analysed module. The article presents examples of calculations for a separate supply chain, which consists of seven links that participate in the flow of processed material. The example aims to show, how to determine the value of PV.

\section{PRIORITY VALUE IN SUPPLY CHAIN PROCESSES}

Various approaches to the supply chain can be found in the literature [Attran 2007, Burgess 2006, Carter 2008, Cooper 1997, Ciesielski 2019]. In the model approach, the supply chain is presented as a system of individual relationships between the links representing the subsequent stages of the processed product that is delivered to the market. However, the SCM definitions in many papers seem to indicate a move away from the chain analogy to a network analogy in many papers. Hertz [Hertz 2001] also discusses Supply Chain Networks as "the network that supplies a specific product or product group following the chain from raw material to the final consumer". Lambert et al. [Lambert et al. 2005] write that "Given that a supply chain is a network of companies, or independent business units, from original supplier to endcustomers, management of this network is a broad and challenging task". Thus supply networks comprise of both "upstream" network of suppliers and "downstream" network of distributors and customers. Similarly to supply chains, networks encompass several dimensions of physical, payment and information flows and also other dimensions such as social, technological, legal and administrative ones. Therefore, the subject of the analysis is the network system, which can of course be limited to one manufacturer or one product (Figure 1).

The supply chain presented in the figure 1 is compatible with the concept of subjective approach to participants in the chain. The links of the presented system are enterprises participating in subsequent stages of production and delivery of the finished product to the market. In this approach, attention is paid to the relationships connecting individual enterprises that form links in the supply chain. However, for the needs of the investigated concept, a process approach to the analyzed supply chains is more justified. Process orientation in supply chain management has been the subject of many scientific and business discussions for several years. Examples of research in this area are articles [Mauoumis et al. 2019, Kotzab and Otto 2004, Lambert et al. 2005]. In this approach, the 
researchers' attention is focused not on enterprises integrating their activities, but on the process integration of subsequent stages of production and delivery of the finished product to the consumer/user. The model layout of the supply chain defined in this way is shown in Figure 2.

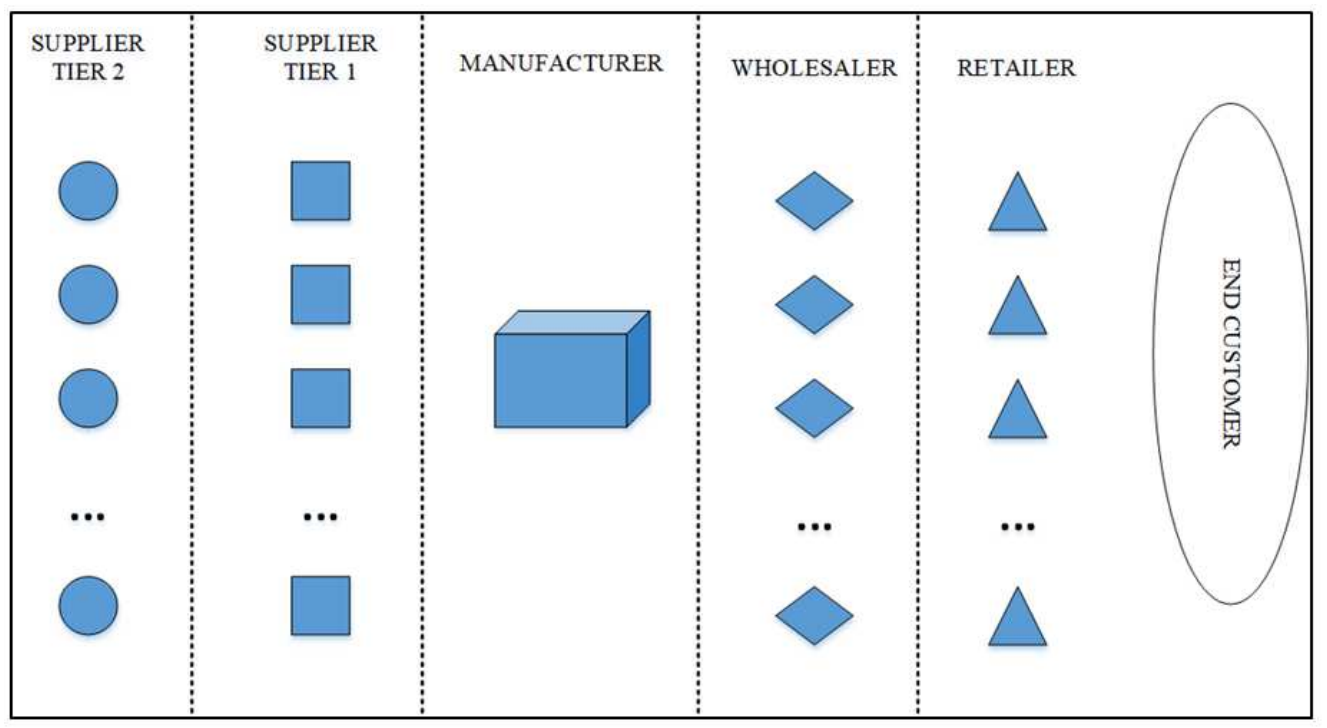

Source: own study

Fig. 1. Supply chain in a subjective approach

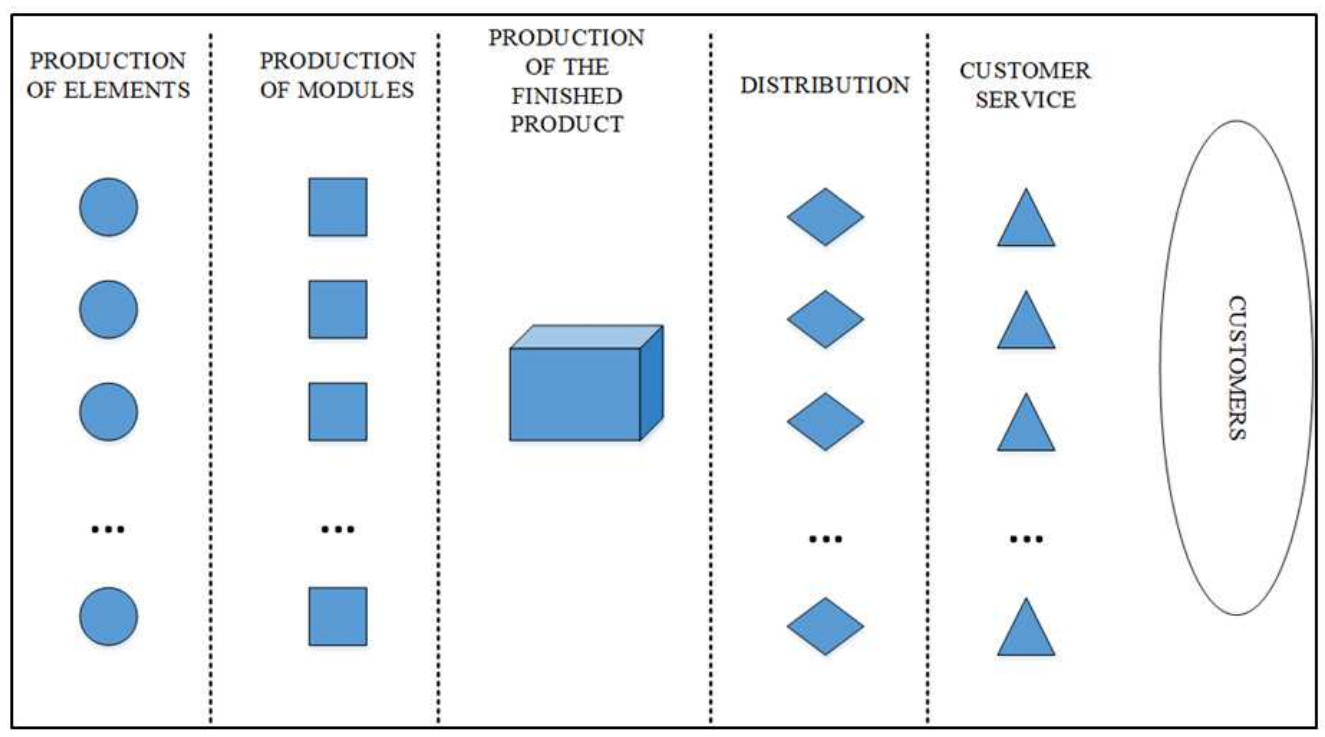

Source: own study

Fig. 2. Supply chain in a process approach

The individual stages of the production and distribution of the finished product are of course carried out by specific companies. However, the lack of an indication of specific companies allows researchers to focus their attention on processes. This allows to increase the flexibility of the entire supply chain and it is in accordance with current trends in supply chain management. This approach also limits existing waste in the traditional supply chain. It is therefore consistent with the concept of LSCM, which is currently being developed in 
published research [Compos et al. 2016, Huo et al. 2019]. At the same time, it is in accordance with the assumptions of the concept of priority value. In this concept, the prepared analyses are focused on the process of performing tasks, and not on the units that are responsible for this process.

The article uses the theory of complex systems [Klir 1976, Mesarovic 1964] to formalize a universal algorithm for developing priority values for any set of different supply chains. In the first stage, the system components were classified into sets of separate subsystems. Then, assessment parameters for separate elementary objects were formulated. These parameters have been divided into three categories: use of available resources, share of maximum storage or processing times and the risk level indicator, which results from not delivering the product to the customer in accordance with the $7 \mathrm{R}$ principle (right product, right place, right quantity, right condition, right time, right customer, right price). In recent years, the last category regarding risk management in the supply chain has become particularly important [Świerczek 2019, Wieteska 2018]. At the same time, the complexity of flows that take place within existing logistics networks is increasing [Turner et al. 2018]. Figure 3 shows a diagram that illustrates the complexity of flows. This complexity is due to the diverse supply chains in any logistics system.

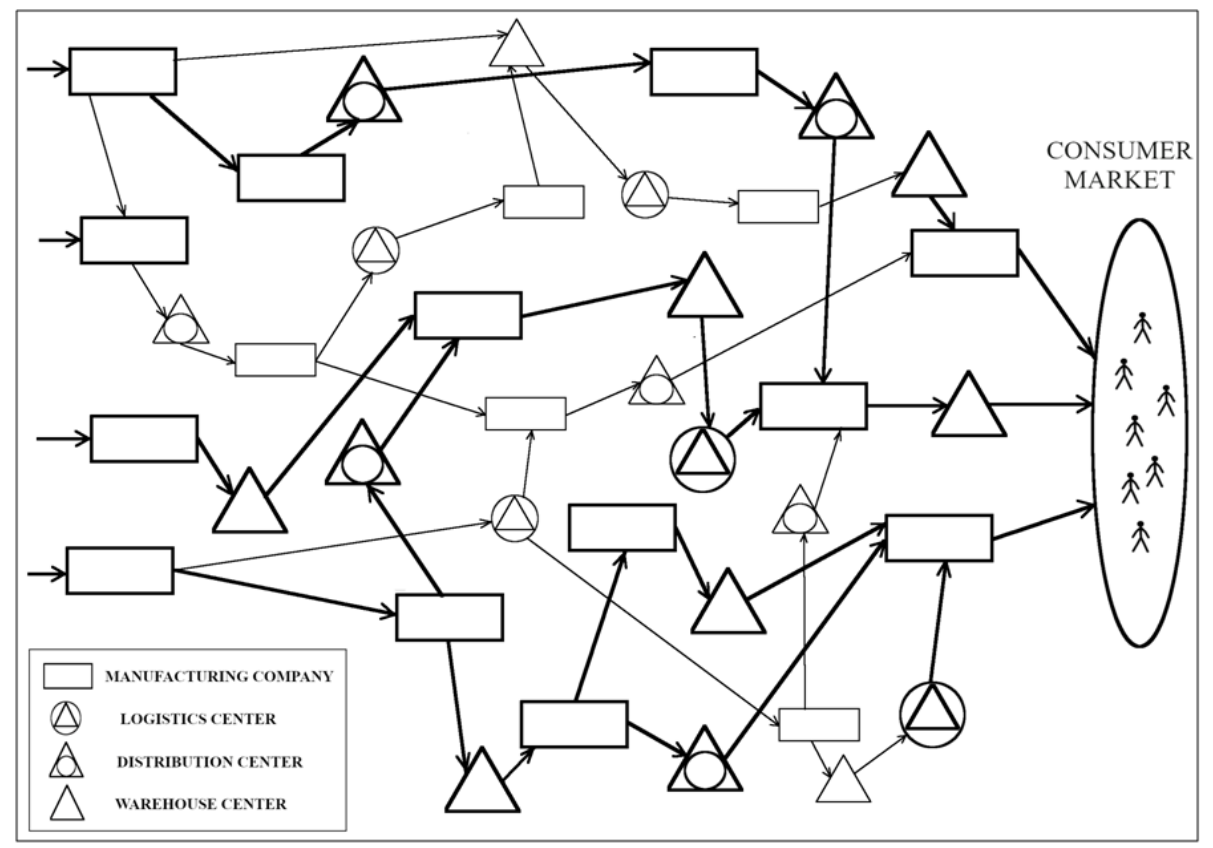

Source: own study

Fig. 3. Complexity of flows in the supply chain

In the considered case, the logistics network model $M_{L S}$ was analyzed. For this network, its modules were classified into two main groups: $P \mid k$ i $C \mid k$. The determination of exact affiliation was determined according to the classification criterion $k$. The point of reference is the customer, who is the recipient of the finished product. The classification criterion was defined as the assignment of possessed properties of a certain binary function in the set $\{0,1\}$. Then:

$$
k \in\{0,1\}
$$

where: $k$ - classification criterion (binary one). 
For $k=1-$ any object (module) of the logistics system $M_{L S}$ is a manufacturing company, i.e. there is at least one process that generates the value of the product from the customer's point of view. Otherwise: $k=0$.

According to such a formal assignment, the modules of the logistics network $M_{L S}$ in the first division are a set of two subsets: 1 - the subset of objects in which value is added to the product, and 2 - the subset of objects in which the necessary temporary storage of the product occurs. Then module of the logistics network $M_{L S}$ is defined as:

$$
M_{L S}=\{P|k, C| k\}
$$

where: $P \mid k$ - set of objects $M_{L S}$, in which there is at least one process generating value added to the product. The assignment of an object to a set $P \mid k$ depends on the criteria $k$ met for $k=1 ; C \mid k$ - set of objects $M_{L S}$, for which $k=0$ - which means that the process that adds value from the customer's point of view is not implemented. In the presented investigations it was assumed that these are network $M_{L S}$ objects in which the storage processes are carried out without distinguishing the length of the storage time.

The set of objects in the system $M_{L S}$ includes both, manufacturing and mining enterprises. This set was formalized as follows:

$$
P \mid k=\left\{P_{i}\right\}_{i \in I}
$$

where: $I$-all possible numbers identifying the enterprise type belonging to $M_{L S}$. There are two ways of numbering $P_{i}$ : first - using numbers that denote the sequential assignment e.g.:

1 - production 2 - mining, 3 - other (others), etc.; the second - direct numbering and classification according to accepted markings, e.g..: $W_{1}, W_{2}, W_{3}, \ldots$ etc.
To the set $C \mid k$ are allocated objects owned by $M_{L S}$, in which there is a storage process. There are different types of such objects in this case: warehouse centres, distribution centres and logistics centres. However, for the purposes of this article, such differentiation is unnecessary. The analysis of multi-variant objects from set $C \mid k$ will be the subject of further research conducted by the authors. Currently, the set $C \mid k$ has been formalized in the overarching approach as follows:

$$
C \mid k=\left\{C_{i}\right\}_{i \in J}
$$

where: $J$-all numbers of possible center types that appear in the analyzed $M_{L S}$.

\section{ALGORITHM FOR DETERMINING PRIORITY VALUES}

The priority value of any logistic system object is determined according to the three criteria: 1 - the level of use $L_{U(X \mid i)} ; 2$ - the maximum possible retention time (and/or processing) in the area of the module under consideration $L_{T(X \mid R)} ; 3$ - risk level participation indicator $L_{F(x \mid R)}$ determined on the basis of Customer Effect Factor [Wiegand et al. 2005, Zwolińska, Kubica 2017a, 2017b]. Priority value $P V$ is determined as the product of three components $L_{U(X \mid i)}, L_{T(X \mid R)}$, $L_{F(X \mid R)}$. Hence:

$$
P V=L_{U(X \mid i)} \cdot L_{T(X \mid R)} \cdot L_{F(X \mid R)}
$$

All three indicators and $P V$ take values in the set $(0,1\rangle$. Accepting the level of individual: $L_{U(X \mid i)}, L_{T(X \mid R)}$ and $L_{F(X \mid R)}$ takes into account the multi-area influences of various factors. The determination of their value is discussed and formalized in the Subsections 3.1, 3.2, and 3.3, while Section 4 presents an example of determining their value. 


\section{Definition of the value of the indicator $L_{U(X \mid i)}$}

The indicator $L_{U(X \mid i)}$ determines the level of the use of individual objects (modules) $M_{L S}$. In the developed analyses there is considered that each isolated module of network model $M_{L S}$ is a shared system, i.e. there are at least two different clients (users) of the facility. The adopted assessment criterion depends on the module of $M_{L S}(P \mid k$ lub $C \mid k$ ), for which the value of $L_{U(X \mid i)}$ is being considered. For production systems $-P \mid k$, the percentage level of utilization of available capacity is determined. In warehouse modules - $C \mid k$, the percentage level of utilization of the available warehouse space is determined. For this reason, the largest parameter value of $L_{U(X \mid i)}$ defines the bottleneck of the entire system throughput. In such a module, time discipline is important, because each oversized exceeding of the task implementation time determines delays in delivery of the final product. Time discipline also applies to all modules of $M_{L S}$, that participate in the flow of the product and precede the bottleneck. It is also introduced index $X$ to determine the level of use $L_{U(X \mid i)}$ of any module of $M_{L S}$. The index $X$ takes determinations $P_{i}$ or $C_{i}$ depending on the analyzed object of $M_{L S}$. Therefore $U_{X \mid i}$-set of shares in the $X$ resources of the specified module:

$U_{X \mid i}=\left\{u_{X \mid 1}, u_{X \mid 2}, \ldots, u_{X \mid K_{X}}\right\}: \sum_{i=1}^{K_{X}} u_{X \mid i}=1 \wedge \forall i=1, \ldots, K_{X}: u_{X \mid i} \in(0,1)$

where: $X$-one module of $M_{L S}$, specifically $P_{i}$ or $C_{i} ; u_{X \mid i}$-client's partial share in the $X$ module resources allocated to him; $i$-customer number assigned to the module $X$, where:

$i \in\left\{1,2, \ldots, K_{X}\right\}, K_{X} \in N_{+}$,
$K_{X}$ - maximum number of clients assigned to the module $X$.

The degree of utilization of the allocated resources $l_{u(X \mid i)}$ from the entire contribution is determined for a module $X$ and an $i$ client. Then: $\forall X \quad \forall i=1, \ldots, K_{X}: l_{u(X \mid i)} \in(0,1\rangle$.

Value $l_{u(X \mid i)}=1$ when the $i$-th client uses the maximum resources $u_{X \mid i}$ of module $M_{L S}$ allocated to him. The $L_{U(X \mid i)}$ value is determined according to the formula:

$L_{U(X \mid i)}=u_{X \mid i} \cdot l_{u(X \mid i)}$

Finally, the $L_{U(X \mid i)}$ value determines the share of the $i$-th client in the total resources of the module $X$. Instead of $L_{U(X \mid i)}$, the $l_{u(X \mid i)}$ value can be used in the algorithm step, which concerns determining the value $P V_{X}$ for a specific module $X$. Then the priority will be determined only to the contracted shares in resources (without taking into account the possibility of increasing the share in case of need).

\section{Determining the value of the $L_{T(X \mid R)}$ indicator}

The value of the $L_{T(X \mid R)}$ indicator is defined in terms of the time criterion. The $L_{T(X \mid R)}$ indicator determines the maximum possible "time window" for the processed material, which does not determine the delay in delivery of the final product. The $L_{T(X \mid R)}$ indicator is determined taking into account two areas of the investigated logistics system:

- the impact of potential time delays on a logistics system module that has been identified as a „bottleneck”,

- impact of potential delays in delivery of the finished product to the final customer. 
It is necessary to determine a set of cumulative transition times to determine the indicator $L_{T(X \mid R)}$. This set is determined on the basis of elementary processing times $t_{y \mid R}$. Then:

$T_{X \mid R}=\sum_{y \in A_{X \mid R}} t_{y \mid R}$

where: $T_{X \mid R}$ - total transition time taking into account the $X$-th type of module and the $R$-th type of product; $t_{y \mid R}$ - elementary handling time for the $R$ product in the $X$-th module; $A_{X \mid R}$ - the set of the all modules of $M_{L S}$, which occur in the $R$ product flow from a fixed $X$ module to the end of the supply chain $K_{P \mid R}$. The index $y$ is a specific object of $M_{L S}$ for a strictly defined product supply chain, which is the beginning of determining the transition time.

The value of the $L_{T(x \mid R)}$ indicator of module $M_{L S}$ depends on the share of the value $T_{X \mid R}$ of the analysed part of the supply chain (i.e. from the determined module $M_{L S}$ to the point $K_{P \mid R}$ ), relative to the maximum possible value of cumulative transition times (flow and/or processing) for a specific product $R$. Then:

$$
L_{T(X \mid R)}=\frac{T_{X \mid R}}{\max _{X}\left\{T_{X \mid R}\right\}}
$$

where: $\max _{X}\left\{T_{X \mid R}\right\}$-maximum possible value $T_{X \mid R}$, which results from the sum of elementary transition times (flow and/or processing) $t_{y \mid R}$, that occurred in the supply chain of product $R$.

\section{Determining the value of the $L_{F(X \mid R)}$ indicator}

The indicator Customer Effect Factor $F_{X \mid R}$ is determined on the basis of the limit level of loss, which results from the consequences of not delivering the product to the customer. The value of the Customer Effect Factor indicator can be determined by using one of three methods:

- intuitive estimation based on expert knowledge,

- using FMEA method - Failure Mode and Effects Analysis,

- using risk analysis techniques.

Different methods of determining the $L_{F(X \mid R)}$ indicator are used depending on the degree of complexity and the level of dynamics of changes in operating states of the analysed system. For modules characterized by stability of operating states in a given $\Delta t$, deterministic values of $F_{X \mid R}$ are assumed. Then they are defined as the average estimated value of the negative impact resulting from delivery delay. FMEA is used to determine the $F_{X \mid R}$ value for systems that show a higher level of structural complexity. The analysis of risk theory is used to determine the $F_{X \mid R}$ value for systems that are characterized by a relatively high level of functional complexity and/or flow.

The subject of the presented investigations is a system that is characterized by a relatively high dynamics of changes in the operating states and a high level of structural and functional complexity as well as flows. Therefore, determining the value of the value of the $L_{F(X \mid R)}$ indicator is estimated using risk theory and the theory of probability. The maximum unwanted random event, that causes a delay in delivery, is defined by $F_{X \mid R}$ for a given $X$ module and a specific $R$ product. Than:

$$
F_{X \mid R}:=\left|\operatorname{VaR}_{\alpha}(X \mid R)\right|
$$


where: $\operatorname{VaR}_{\alpha}(X \mid R)$ - value at risk, that is, the loss value determined for the single $X$ module and the specific $R$ product at the $\alpha$ level of probability.

Then the value of the $L_{F(X \mid R)}$ indicator is determined by:

$$
L_{F(X \mid R)}=\frac{F_{X \mid R}}{\max _{X}\left\{F_{X \mid R}\right\}}
$$

where: $\max _{X}\left\{F_{X \mid R}\right\}$ - maximum possible loss that occurred in all $X$ modules for specific $R$ product in the situation where we consider the $M_{L S}$ system as a whole.

In the conducted research it is required, that a single event, for which the value at risk $V a R$ is determined, is a random variable, that is consistent with the probability distribution belonging to the class of elliptical distributions. For example, it can be a random variable with a normal distribution, which have any parameters $\mu$ and $\sigma$, being any component of a set multidimensional Gaussian distribution.

\section{CASE STUDY}

Determining the value $P V_{X}$ of all the modules of any logistics system is a timeconsuming task and belongs to the class of NPhard task. The formalization of the algorithm for NP-hard tasks can be expressed by a polynomial equation, while the time for determining the solution increases exponentially with the increase in the number of elementary objects of $M_{L S}$. Therefore, the verification of the presented algorithm was carried out for single supply chain. It was assumed that the investigated exemplary supply chain consists of 7 modules involved in material flow stream performance, including 4 production systems in it.

In order to determine the $P V_{X}$ value of the individual modules of the investigated supply chain, levels of indicators $L_{U(X \mid i)}, L_{T(X \mid R)}$ and $L_{F(X \mid R)}$ should be defined. These indicators were determined for selected numbers of module $X \in M_{L S}$ later in the article.

The value of $L_{U(X \mid i)}$ indicator defines the degree of utilization of the allocated share in resources of $X$ module by the $i$-th client. Knowing that the resources of the $X$ module are shared by 7 users, and each user has a strictly allocated share: $u_{(X \mid 1)}=32 \%$, $u_{(X \mid 2)}=19 \%, \quad u_{(X \mid 3)}=15 \%, \quad u_{(X \mid 4)}=11 \%$, $u_{(X \mid 5)}=9 \%, u_{(x \mid 6)}=8 \%, u_{(x \mid 7)}=6 \%$; then for the customer number 1 for whom $l_{(X \mid 1)}=0,7$ the value $L_{U(X \mid 1)}$ is determined according to:

$$
L_{U(X \mid 1)}=u_{(X \mid 1)} \cdot l_{(X \mid 1)}=0,32 \cdot 0,7=0,224
$$

Level $l_{(X \mid 7)}=0,7$ means that the first customer used $70 \%$ of the $32 \%$ of the $X$ module resources allocated to him. However the value $L_{U(X \mid 1)}=0,224$ indicates the degree of complete use of the resources of $X$ module only by the first customer.

The value of $L_{T(X \mid R)}$ indicator for the $R$ product is determined by the cumulative share of transition, flow and/or processing time from the analysed $X$ module to the end of the $K_{P \mid R}$ supply chain related to the maximum flow time that can occur for the $R$ product in the examined supply chain. It should be noted that the elementary time values $t_{X \mid R}$ estimated for modules $C_{i}$ and inter-operational buffers in the set $P_{i}$, are determined by customer's tact and the level of the $R$ product inventory (or components needed to produce it).

Knowing that: $T_{|| R}=\sum_{y \in A_{|| R}} t_{y \mid R}=15 j, \quad T_{2 \mid R}=10 j$, $\ldots, T_{4 \mid R}=17 j, \ldots, T_{7 \mid R}=5 j$. Then: 


$$
L_{T(1 \mid R)}=\frac{T_{1 \mid R}}{\max _{X}\left\{T_{X \mid R}\right\}}=\frac{T_{1 \mid R}}{T_{4 \mid R}}=0,882
$$

and

$$
L_{T(2 \mid R)}=\frac{T_{2 \mid R}}{\max _{X}\left\{T_{X \mid R}\right\}}=\frac{T_{2 \mid R}}{T_{4 \mid R}}=0,588
$$

The fourth module is the bottleneck in the examined case according to the criterion of flow time (and/or processing). For its $L_{T(4 \mid R)}=1$. Therefore, it is extremely important to adhere to the discipline of the time of completion of all tasks carried out in the area of this module and in the facilities preceding the fourth module.

The value of the Customer Effect Factor $F_{X \mid R}$ for a single object $M_{L S}$ is determined on the basis of the limit level of loss that is a consequence of not delivering the recipient's product. Value at risk is referred to as:

$\operatorname{VaR}_{\alpha}\left(Y_{X \mid R}\right)=-\sup \left\{x \in R: P\left(Y_{X \mid R} \leq x\right) \leq \alpha\right\}=-q_{\alpha}^{+}\left(Y_{X \mid R}\right)$

where: $q_{\alpha}^{+}\left(Y_{X \mid R}\right)$ - upper order quantile $\alpha$ of the variable $Y_{X \mid R}$.

Based on the definition (12) and formula (13) were obtained:

$$
F(X \mid R)=\left|-q_{\alpha}^{+}\left(Y_{X \mid R}\right)\right|
$$

Then:

$$
L_{F(X \mid R)}=\frac{\left|-q_{\alpha}^{+}\left(Y_{X \mid R}\right)\right|}{\max _{X}\left\{\left|-q_{\alpha}^{+}\left(Y_{X \mid R}\right)\right|\right\}}
$$

Knowing the parameters of the distribution of the random variable $Y_{X \mid R}$ determining the value of loss defined for a single module $X$ and a specific product $R$ at a given level $\alpha$, it is possible to designate $F_{X \mid R}$, when the parameters of the random variable $Y_{X \mid R}$ distribution estimating the value of the loss defined for the single $X$ module and the specific $R$ product at a predetermined $\alpha$ level are known. For each module $X$ and for each $R$ product, it is possible to set any $\alpha$ level. Then $\alpha$ is dependent on $X$ and $R$, then: $\alpha_{X \mid R}$. For example, if the random variable $Y_{5 \mid R}$ specifying the processing (or storage) time is defined by distribution $Y_{5 \mid R} \sim \operatorname{Normal}(7,1)$, while the risk protection is set at the level $\alpha_{5 \mid R}=95 \%$, then:

$$
\operatorname{VaR}_{0,95}\left(Y_{5 \mid R}\right)=-q_{0,95}^{+}\left(Y_{5 \mid R}\right)=-8,64 j
$$

Then:

$$
F(5 \mid R)=\left|-q_{0,95}^{+}\left(Y_{5 \mid R}\right)\right|=8,64
$$

It is possible to specify the value of $L_{F(X \mid R)}$ , if the value of all $F(X \mid R)$ for each module participating in the flow (or processing) of the $R$ product is known. For fixed distribution parameters $\mu, \sigma$ of the random variable $Y_{X \mid R}$ determined in the analysed example: $F(1 \mid R)=G G G, \quad F(2 \mid R)=G G G$, $F(3 \mid R)=G G G, \quad \ldots, \quad F(7 \mid R)=G G G ;$ such that: $\max _{X}\left\{F_{X \mid R}\right\}=F_{3 \mid R}$. Then:

$$
L_{F(X \mid R)}=\frac{F_{X \mid R}}{\max _{X}\left\{F_{X \mid R}\right\}}=\frac{F_{X \mid R}}{F_{3 \mid R}}
$$

For the third module: $X=3$, the $L_{F(X \mid R)}$ indicator reaches a maximum value of one: $L_{F(3 \mid R)}=1$. 


\section{RESULTS}

The algorithm for determining the priority value $P V_{X}$ of logistics system modules has been defined in three areas: the use of level indicator $L_{U(X \mid i)}$, flow time indicator $L_{T(X \mid R)}$ and $L_{F(X \mid R)}$ - indicator of risk of loss incurred as a result of non-delivery of a product in accordance with the $7 \mathrm{R}$ principle (right product, right place, right quantity, right condition, right time, right customer, and right price). It is necessary to calculate all three indicators according to the presented method for each module separately in order to determine the module with the highest priority value. Then determine the values $P V_{X}$ according to formula (5). In table 1 summarizes sample values $L_{U(X \mid i)}, L_{T(X \mid R)}$, $L_{F(X \mid R)}$ and $P V_{X}$.

Table 1. Summary of the values of the analyzed indicators

\begin{tabular}{|c|c|c|c|c|c|c|c|}
\hline Indicators & $X=1$ & $X=2$ & $X=3$ & $X=4$ & $X=5$ & $X=6$ & $X=7$ \\
\hline$L_{U(X \mid i)}$ & 0.012 & 0.364 & 0.275 & 0.485 & 0.284 & 0.958 & 0.224 \\
\hline$L_{T(X \mid R)}$ & 0.882 & 0.588 & 0.516 & 1 & 0.781 & 0.946 & 0.735 \\
\hline$L_{F(X \mid R)}$ & 0.198 & 0.528 & 1 & 0.278 & 0.116 & 0.295 & 0.559 \\
\hline$P V_{X}=L_{U(X \mid i)} \cdot L_{T(X \mid R)} \cdot L_{F(X \mid R)}$ & 0.002 & 0.113 & 0.141 & 0.134 & 0.025 & 0.267 & 0.092 \\
\hline$P V_{X} \cdot 10^{3}$ & 2.095 & 113.0 & 141.9 & 134.8 & 25.7 & 267.4 & 92.03 \\
\hline
\end{tabular}

Due to the transparency of the determined values $P V_{X}$, they were scaled into a set of numbers in the scope of: $(0,1000)$. In the presented example, the option of determining $P V_{X}$ for the specified product for which the $i$ th customer's demand occurrence was considered. In the same way, one can considers values $P V_{X}$ for orders consisting of several freely different products offered on the consumer market, taking into account proportional shares. The degree of difficulty in determining the value $P V_{X}$ increases exponentially with the increase in the number of variables considered in the system and the number of components of the system.

\section{CONCLUSIONS}

The article presents the algorithm for determining the priority of any logistics network module. The presented method makes it possible to determine the critical elements of a complex system and at the same time considers it in a holistic approach. The method presented focuses on the implementation of operational level processes. For this reason, the presented algorithm belongs to the class of NPdifficult tasks, because it takes into account the comprehensiveness and hierarchical relationships of the components. The final value $\mathrm{PV}_{\mathrm{x}}$ determined covers three different areas of assessment: use of owned (or contracted) resources, the effect of the flow of time (or processing) with respect to the bottleneck and / or shipping and the level of risk that results from the delayed delivery.

Further research of the authors will be focused on developing the model that was presented in the article. An area requiring further analysis is e.g. the impact of damage to selected machines on the level of customer service rendered depending on the adopted service strategy and the priority given to the customer. The possible development of the model may also take into account the impact of substitutability of the production materials used and the strategy of managing relations with suppliers.. 


\section{ACKNOWLEDGMENTS AND FUNDING SOURCE DECLARATION}

This work was supported funded by research project AGH University of Science and Technology 11.11.130.758.

\section{REFERENCES}

Attran M., Attran S., 2007. Collaborative supply chain management, the most promising practice for building efficient and sustainable supply chains. Business Process Management Journal, 13 (3), 390404,

http://doi.org/10.1108/14637150710752308

Burgess K., Singh P., Koroglu R., 2006. Supply Chain Management: A Structured Literature Review and Implications for Future Research. International Journal of Operations and Production Management, 26 (7), 703-729, http://doi.org/10.1108/01443570610672202

Campos L.M.S., Vazquez-Brust D.A., 2016. Lean and green synergies in supply chain management. Supply Chain Management, 21 (5), 627-641, http://doi.org/10.1108/SCM-03-2016-0101

Carter C., Rogers D., 2008. A framework of sustainable supply chain management: moving toward new theory. International Journal of Physical Distribution \& Logistics Management, $38 \quad$ (5), 360-387, http://doi.org/10.1108/09600030810882816

Ciesielski M., Konecka S., 2019. The main areas of methodological reflection in the supply chains research. LogForum 15 (3), 351-361, http://doi.org/10.17270/J.LOG.2019.341

Cooper M.C., Lambert D.M., Pagh J.D, 1997. Supply Chain Management. More Than a New Name for Logistics. The International Journal of Logistics Management, 8 (1), 113.

Hertz S., 2001, Dynamics of Alliances in Highly Integrated Supply Chain Networks. International Journal of Logistics: Research Applications, 4 (2), 237-256, http://doi.org/10.1080/13675560123649.
Huo B., Gu M., Wang Z., 2019. Grean or lean? A supply chain approach to sustainable performance. Journal of Cleaner Production, 216, 152-166, http://doi.org/10.1016/j.jclepro.2019.01.141

Klir J.G., 1976. Ogólna teoria systemów. Wydawnictwo WNT, Warszawa.

Kotzab H., Otto A., 2004. General processoriented management principles to manage supply chains: theoretical identification and discussion, Business Process Management Journal, 10 (3), 336-349

http://doi.org/10.1108/14637150410539731

Lambert D., García-Dastugue S., Croxton K., 2005. An evaluation of process-oriented supply chain management frameworks. Journal of Business Logistics, 26 (1), 2551 ,

http://doi.org/10.1002/j.21581592.2005.tb00193.x.

Mauoumis S.M., Kazemi N., Abdul-Rashid S.A., 2019. Sustainable Supply Chain Management in the Automotive Industry: A Process-Oriented Review, Sustainability, 11 (14), 3945, http://doi.org/10.3390/su11143945

Mesarovic M.D., 1964. The Control of Multiverible Systems. New York, Wiley

Świerczek A., 2019. The effects of demand planning on the negative consequences of operational risk in supply chains, LogForum 15 (3), 315-329, http://doi.org/10.17270/J.LOG.2019.340

Turner N., Aitken J., Bozarth C., 2018, A framework for understanding managerial responses to supply chain complexity, International Journal of Operations \& Production Management, 38 (6), 1443-1466, http://doi.org/10.1108/IJOPM-01-2017$\underline{0062}$

Wiegand B., Langmaack R., Baumgarten T., 2005. Lean Maintenance System Zero Maintenance Time - Full Added Value Workbook, Lean Institute, Portsmouth U.S.A.

Wieteska G., 2018, The domino effect disrupttions in supply chains, LogForum 14 (4), 492-506, http://doi.org/10.17270/J.LOG.2018.302 
Zwolińska B., Kubica Ł., 2017a. Model of designating the critical damages Part 1: Description and analysis of the production system, Journal of KONBiN, 42, 329-352, http://doi.org/10.1515/jok-2017-0032

Zwolińska B., Kubica Ł., 2017b. Model of designating the critical damages Part 2: The probabilistic model of shaping Machine's Priority Number, Journal of KONBiN, 42, 353-378, http://doi.org/10.1515/jok-2017-0033
Zwolińska, B., 2019, Modeling convergent processes in complex production systems, Wydawnictwa AGH, Kraków

\section{ALGORYTM KSZTALTOWANIA PRIORYTETÓW W LAŃCUCHU DOSTAW}

STRESZCZENIE. Wstęp: W pełni efektywne zarządzanie i organizacja dowolnego systemu produkcyjnego zakłada: zero zapasów w całym łańcuchu dostaw oraz zero postojów spowodowanych np.: oczekiwaniem na przetwarzany materiał bądź losowo występującymi awariami urządzeń wyposażenia technicznego. W wielu przedsiębiorstwach elementarne ograniczanie strat $\mathrm{z}$ grup: muri, mura i muda, przynosi doraźne efekty jedynie w usprawnianym obszarze. Należy pamiętać, że system wytwórczy zgodnie z teorią systemów złożonych jest organizacją, w której elementy składowe systemu występują względem siebie w ścisłej korelacji. Każdorazowa zmiana będąca obszarowym usprawnieniem systemu, determinuje również zmiany w innych (nie usprawnianych) obszarach. Stąd konieczne jest stosowanie wieloaspektowego ujęcia z jednoczesnym uwzględnieniem horyzontu czasowego i przestrzennego.

Materiały i rezultaty: Przedstawiony $w$ artykule problem badawczy skupia się na obszarze poziomu operacyjnego (wykonawczego) i nie dotyczy rozwiązań taktycznych ani strategicznych. Przedstawiony w artykule algorytm kształtowania liczby priorytetowej obiektów, będących wyposażeniem dowolnie rozważanego systemu produkcyjnego, uwzględnia stany pracy w obszarach zewnętrznym i wewnętrznym analizowanego układu. Mianowicie uwzględnione zostały: wartości poziomów pracy w łańcuchu dostaw (do i z przedsiębiorstwa) oraz wartości poziomów pracy układu wewnątrz przedsiębiorstwa $\mathrm{w}$ obszarze ciągłości przepływu przetwarzanego materiału oraz poziomów awaryjności urządzeń wyposażenia technologicznego. Zaprezentowany algorytm oceny priorytetów obiektów obejmuje kompleksowe ujęcie występującej synergii pojedynczego elementu systemu z całym układem (z uwzględnieniem wpływów czasu i miejsca).

Opracowany algorytm poddano weryfikacji na wybranym przykładzie systemu produkcyjnego. Zaprezentowana metoda kształtowania priorytetów wymaga dostosowania metodyki oceny do indywidulanych cech rozważanego obiektu , przy każdorazowym jej zastosowaniu. $\mathrm{Z}$ tego też względu analiza uwzględnia między innymi: typ i rodzaj systemu, jego złożoności w obszarze strukturalnej, funkcjonalnej i złożoności współdziałania oraz wielkości strumieni przepływu materiałów i ich częstotliwość.

Przedstawiona $\mathrm{w}$ artykule metoda oceny priorytetów, umożliwia wyznaczenie krytycznych elementów złożonego systemu. Ocena kształtowana jest w układzie trójwymiarowym z uwzględnieniem awarii maszyn, procesów realizacji w obszarze analizowanego systemu wytwórczego, ale również z uwzględnieniem poziomów pracy systemów zasilających (łańcuchów dostaw). Ze względów na złożoność przedstawionego algorytmu, w artykule zaprezentowano wyniki dla układu cechującego się względnie wysokim poziomem elastyczności procesowej oraz posiadającym względnie dużą liczbę procesów technologicznych. Ważnym parametrem analizowanego systemu jest wysoki poziom jakości realizacji procesów osiągając skumulowaną jakość dla wytworzonych produktów ponad cztery sigma w kryterium oceny zgodnym z metodą Six Sigma. Ponadto układ cechuje się względnie dużą zmiennością asortymentową materiałów wejściowych, co w rezultacie determinuje wielką liczbę łańcuchów dostaw na wejściu do systemu produkcyjnego. Ponadto specyfika rozpatrywanej branży jest układem wykazującym konkurencyjność wytwarzanych wyrobów finalnych stąd występuje wysoki poziom dostosowania produktów do oczekiwań klientów przekładający się na elastyczność przedsiębiorstwa. 
Wnioski: Opracowany algorytm uwzględnia rozważania ujęcia systemowego zgodnie z ogólną teorią systemów według Klira oraz Meserovicza. Zaprezentowany algorytm jest ogólnym ujęciem oceny elementarnych obiektów systemu z jednoczesnym uwzględnieniem występującej synergii między pozostałymi elementami całego układu. W kolejnych etapach badań zostaną opracowane algorytmy dla różnych układów produkcyjnych (konwergentnych i dywergentnych), o różnej specyfikacji wytwórczej (przedmiotowej i technologicznej) oraz wykazujących różne poziomy wartości elastyczności procesowej. Dla opracowanych algorytmów zostanie przeprowadzona walidacja i porównanie modeli dla danych empirycznych zgromadzonych w rzeczywistych obiektach wytwórczych.

Słowa kluczowe: priorytety obiektów, łańcuch dostaw

Bożena Zwolińska ORCID ID: https://orcid.org/0000-0002-8770-091X

AGH University of Science and Technology, al. Mickiewicza 30, 30-059 Kraków, Poland

phone +48 600393943

e-mail: bzwol@agh.edu.pl

Agnieszka A. Tubis ORCID ID: https://orcid.org/0000-0003-2993-036X

Wroclaw University of Science and Technology

ul. Wyspiańskiego 27, 50-370 Wrocław, Poland

phone +48 713203427

e-mail: agnieszka.tubis@pwr.edu.pl 